\title{
SILICON IN A SUSTAINABLE CROPPING SYSTEM
}

\author{
Margit Olle \\ Estonian Crop Research Institute, J. Aamissepa 1, 48309, Jogeva alevik, Jogeva alevik, ESTONIA \\ Corresponding author, margit.olle@gmail.com
}

Communicated by Ina Alsiṇa

The purpose of this review was to show the importance of silicon (Si) in agricultural production. $\mathrm{Si}$ is a second most abundant element both on the surface of the earth and in the soil. Si in plants leads to an increase in horticulture production. It has been demonstrated to have multiple direct and indirect beneficial effects on growth and development of many plants. The beneficial effects of Si are especially pronounced in the plants exposed to abiotic and biotic stresses. Si enhances tolerance of plants to metal toxicity. Si uptake by plants improves agricultural crop quality and yield. Si application could therefore improve crop production under adverse climate and soil conditions. Si can positively influence plant growth and yield, in particular, under stress conditions. Si may increase the uptake and translocation of mineral elements in plants. The application of stabilised silicic acid is called the 'silicic acid agro technology' (SAAT). SAAT increases root system size, length of stem/tillers, leaf area, chlorophyll content and nutrient uptake, resulting in higher yield and improved. SAAT decreases effect of biotic and abiotic stresses. Therefore, SAAT is proposed as an element in sustainable cropping strategies.

Key words: cultivation, nutrient uptake, plant stress, Si, yield.

\section{INTRODUCTION}

$\mathrm{Si}$ is a second most abundant element both on the surface of the earth and in the soil (Olle, 2014). Most Si in soil is insoluble and not available to plants because of formation of oxides or silicates in combination with other elements (Ali et al., 2013; Balakhnina Borkowska, 2013). The occurrence of $\mathrm{Si}$ in plants is a result of its uptake in the form of soluble $\mathrm{Si}(\mathrm{OH})_{4}$ (Ma Yamaji, 2006) or $\mathrm{Si}(\mathrm{OH})_{3} \mathrm{O}_{2}$, from the soil and its controlled polymerisation at the final location. However, the ability of a plant to accumulate $\mathrm{Si}$ varies greatly between species (0.1-10\% of dry weight) (D'Imperio et al., 2016).

$\mathrm{Si}$ is beneficial for mostly higher plants, especially in a stressful environment, although it is not considered to be required by higher plants (Chen et al., 2011).

Si uptake in plants leads to an increase in horticulture production (D'Imperio et al., 2016). It has been demonstrated to have multiple direct and indirect beneficial effects on growth and development of many plants, particularly of gramineous and some cyperaceous plants (Ali et al., 2013). $\mathrm{Si}$ has been shown to enhance growth of various plants (Jana and Jeong, 2014). The beneficial effects of Si are especially pronounced in plants exposed to abiotic and biotic stress (Ma, 2004; Gomes et al., 2005; Epstein, 2009; Vaculik et al., 2012; Ali et al., 2013; D'Imperio et al., 2016; Reynolds et al., 2016). Si enhances tolerance of plants to metal toxicity (Richmond and Sussman, 2003), including aluminum ( $\mathrm{Al}$ ), boron (B), cadmium (Cd), manganese (Mn), and zinc (Zn) (Ali et al., 2013). Si uptake by plants improves agricultural crop quality and yield (Richmond and Sussman, 2003). Si application could therefore improve crop production under adverse climate and soil conditions (Zhu Gong, 2014, Guntzer et al., 2012).

The purpose of this investigation was to show the importance of $\mathrm{Si}$ in agricultural production.

\section{OVERVIEW OF THE SI CYCLE BETWEEN SOIL AND PLANTS}

Presence of Si both in soil and plants protects plants against biotic and abiotic stresses are as follows (Farooq and Dietz, 2015).

Si associated ex planta benefits:

- alleviation of heavy metal toxicity e.g. Fe, Al, Mn, As, Cd etc.; 
- alleviation of $\mathrm{P}$ deficiency.

Si associated in planta benefits are increase of resistance against:

- abiotic stressors: drought, lodging, low and high temperature, UV light, heavy metals, and salinity;

- biotic stressors: diseases, fungi, pathogens, herbivores.

Si uptake in higher plants can be active, passive and rejective uptake. Si uptake by rice, a typical Si-accumulator, is an active process that is not affected by transpiration, but is severely inhibited by respiratory inhibitors like $\mathrm{NaCN}$ and metabolic inhibitors such as 2,4-dinitrophenol (2,4-DNP), iodo-acetate and 2,4-dichlorophenoxyacetic acid (Liang et al., 2005). Some dicots, such as cucumber, melon, strawberry and soybean, take up Si passively, and bean excludes $\mathrm{Si}$. Plants with an active $\mathrm{Si}$ uptake process have much higher intake of Si than of water, resulting in Si depletion in nutrient solutions (Liang et al., 2005). Those with a passive or rejective $\mathrm{Si}$ uptake system take up $\mathrm{Si}$ at a rate similar to or even much lower than water. In addition to rice, some graminaceous plants and some cyperaceous plants take up Si actively, while uptaqke of some other Gramineae is passive (Liang et al., 2005).

Si nutrition was shown to ameliorate the deleterious effects of salinity on growth of canola plants, by lower tissue $\mathrm{Na}^{+}$ contents, which maintained the membrane integrity of root cells, increased reactive oxygen species scavenging capacity and reduced lignification (Hashemi et al., 2010).

Si supplementation leaves no insecticide residues in food or the environment, is relatively cheap, and could easily be integrated with other pest management practices, including biological, chemical, and cultural practices (Laing et al., 2006).

Converting silicic acid to silica in higher plants. Most important role of photosynthetic organisms in the Si cycle is conversion of silicates to silicic acid on land and silicic acid to silica in the ocean. However, terrestrial higher plants are also involved in the conversion of silicic acid to silica. Silicic acid enters the plants, as does water, and is carried through the plant with water flow via transpiration. As water evaporates, silicic acid becomes supersaturated with respect to solid hydrated silica, which is precipitated as phytoliths. These phytoliths are resolubilised and join the flux of silicic acid to the ocean. Silica deposits provide increased resistance to parasites and alter leaf posture in many plants (Raven, 2003).

Si uptake, transport and accumulation in plants. There have been some recent advances on understanding of Si uptake, transport, and accumulation in plants and on how $\mathrm{Si}$ alleviates salinity toxicity and drought stress. The major points are the following (Zhu Gong, 2014):

1) both passive and active $\mathrm{Si}$ uptake may coexist in plants;
2) although $\mathrm{Si}$ transporters have been identified in some plants, more Si transporters remain to be identified, and the process of Si transport needs further clarification;

3) the mechanisms for Si-mediated tolerance of salinity and drought have been extensively investigated at both physiological and biochemical levels. The physiological aspects include increasing water uptake by roots, maintaining nutrient balance, decreasing water loss from leaves, and promoting photosynthetic rate. At the biochemical level, Si may improve antioxidant defence abilities by increasing the activities of antioxidant enzymes and the contents of non enzymatic antioxidants; $\mathrm{Si}$ may also contribute to osmotic adjustment and increase photosynthetic enzymatic activities;

4) Si can regulate the levels of endogenous plant hormones under stress conditions, whereas Si involvement in signalling and regulation of gene expression related to increasing stress tolerance remains to be explored.

\section{SIGNIFICANCE OF SI FOR PLANT GROWTH AND YIELD}

$\mathrm{Si}$ is applied to improve plant growth and yield, also under stress conditions. Several functions have been attributed to Si: improvement of nutrient imbalance, reduction of mineral toxicities, improvement of mechanical properties of plant tissues and enhancement of resistance to other various abiotic (salt, metal toxicity, nutrient imbalance, lodging, drought, radiation, high temperature, freezing, UV) and biotic stresses. The protective role of Si in plants may be connected with accumulation of polysilicic acids inside cells. An increase in the concentration of polysilicic acid in plant tissues has been shown to increase stress tolerance (Balakhnina and Borkowska, 2013).

Si application increased seed germination, plant growth, biomass, and photosynthesis under drought and salt stress. This Si-mediated increase in plant growth and biomass under drought and salt stress might be due to followed reasons. Si-mediated alleviation of both drought and salt stress include nutrient homeostasis, modification in gas exchange attributes and phytohormones, osmotic adjustment and higher leaf water content, reduction in oxidative stress by enhancing the activities of antioxidant enzymes, and upregulation of gene expression. In addition, Si-mediated increase in plant growth and biomass might be due to reduction in $\mathrm{Na}^{+}$uptake and translocation and increase in $\mathrm{K}^{+}$uptake and translocation as well as reduction of free $\mathrm{Na}^{+}$in plants (Rizwan et al., 2015).

Similarly, it was reported that $\mathrm{Si}$ improves water storage within plant tissues, which allows a higher growth rate that, in turn, contributes to salt dilution in the plant, mitigating salt toxicity effects (Romero-Aranda et al., 2006). 


\section{INTERACTION OF SI WITH THE UPTAKE OF MIN- ERAL ELEMENTS}

Olle (2017) showed that the content of $\mathrm{NO}_{3}, \mathrm{~N}, \mathrm{P}, \mathrm{Ca}$ was higher in Si-treated plants. Similarly, Smith (2011) found that applied Si fertilisers interacted positively with applied major and trace elements improving plant agronomic performance and efficiency. Bent (2014) observed that Si acid increases nutrient uptake in plants.

Increased nitrate uptake can influence plants negatively. High nitrate accumulation in plants might be undesirable, because it results in nitrite production, which is converted to nitric oxide by nitrate reductase and further into the extremely toxic compound peroxynitrite under aerobic conditions, which is harmful for plant growth (Reddy and Menary, 1990).

Olle (2017) showed that when plants were treated with silicic acid solution, the phosphorus $(\mathrm{P})$ content was higher than in the untreated control. Greger et al. (2011) found that when lettuce plants were treated with silicic acid solution, the $\mathrm{P}$ content was lower. This observed decrease of $\mathrm{P}$ was mainly a dilution effect; in fact the amount of $\mathrm{P}$ was unchanged or increased, as there was Si-induced increase of biomass (Greger et al. 2011). Increased P content is important, because it results in good root growth (Durner, 2013).

Si treatment increased calcium contents in iceberg lettuce plants (Olle, 2017). A higher Ca content is beneficial, suppressing insect and disease attack and increasing transportability and storage quality (Olle, 2013; 2015).

Plants absorb $\mathrm{Si}$ as $\mathrm{H}_{4} \mathrm{SiO}_{4}$. At the $\mathrm{pH}$ levels of most agricultural soils, $\mathrm{H}_{4} \mathrm{SiO}_{4}$ concentration in soil solution ranges from 0.1 to $0.6 \mathrm{mM}$. Absorption of $\mathrm{H}_{4} \mathrm{SiO}_{4}$ takes place at the lateral roots via active, passive, and rejective mechanisms. It is believed that in high $\mathrm{Si}$ accumulators the amount of $\mathrm{H}_{4} \mathrm{SiO}_{4}$ taken up by active mechanisms is greater than concentrations taken by mass flow, because of the high density of $\mathrm{Si}$ transporters in roots and shoots facilitating $\mathrm{H}_{4} \mathrm{SiO}_{4}$ movement across root cell membranes (Tubana et al., 2016).

Cucumber and courgette could benefit from enhanced Si concentration in the root environment, it can promote total yield and suppress powdery mildew. Despite minor uptake of Si in lettuce, it was found that Si uptake affected the Mn distribution, thereby, alleviating Mn toxicity in the plant (Datnoff et al., 2001).

\section{INTERACTION BETWEEN SI AND STRESS FACTORS}

The presence of $\mathrm{Si}$ in plants has been found to alleviate many abiotic and biotic stresses, leading to the incorporation of silicates into many fertilisers (Currie and Perry, 2007). Si interacts with polyphenols in xylem cell walls and affects lignin deposition and biosynthesis. In rice, under water deficit induced by polyethylene glycerol, addition of Si was observed to decrease the transpiration rate and mem- brane permeability. In sorghum, application of Si increased the relative water content and dry mass of plants (Balakhnina and Borkowska, 2013). Si has been reported to promote resistance of wheat to freezing stress. Physiological and cytological studies suggested that the Si-induced defence response and cell silicification of rice leaves altogether contribute to the $\mathrm{Si}$-induced rice resistance to blast disease (Chen et al., 2011). Si also can alleviate the effects of salt stress, high temperature, and heavy metals toxicity on plants. The improvement of drought tolerance in sorghum achieved by adding Si might be associated with enhancement of water uptake ability. Si uptake also can improve water status and increase dry mass of wheat plants in pots under drought (Balakhnina and Borkowska, 2013). In the context of organic farming, the application of Si to not only cereals, millets, sugarcane etc. but also to vegetables and pulses may pave a way for increasing the yield and reducing the use of chemical fertilisers, pesticides and fungicides (Vasanthi et al., 2014).

Possible mechanisms of beneficial action of $\mathrm{Si}$ on cell physiology and stress acclimation (Farooq and Dietz, 2015) are:

- Si at high concentrations changes physicochemical properties, which affect solubility, binding and sequestration of other elements ex planta and in planta;

- Si may bind to proteins such as effector proteins and receptors or compete with other binding processes in the cell or on the cell surface.

The beneficial effects of Si are high deposition in plant tissues, enhancing their strength and rigidity. Si might play an active role in promoting host resistance to plant diseases by stimulating defence reaction mechanisms (Ma and Yamaji, 2006).

Biotic stresses. The beneficial role of $\mathrm{Si}$ in promoting plant resistance to various biotic (i.e. pest attack and pathogen infection) is particularly evident. Si is deposited mainly in the cell lumen and cell wall in the form of $\mathrm{SiO}_{2} * \mathrm{nH}_{2} \mathrm{O}$. Plants take up $\mathrm{Si}$ in the form of monosilicic acid. There are numerous reports on $\mathrm{Si}$ suppressing plant diseases and pests. $\mathrm{Si}$ mediated resistance to the pathogen is associated with higher deposition of $\mathrm{Si}$ in leaves and the activation of host defence response (Gao et al., 2011).

Photosynthetic traits such as gas exchange and chlorophyll fluorescence parameters have been considered to be very useful, non-invasive indicators to investigate the behaviour of the photosynthetic apparatus under environmental stress, including pathogen attack. When plants were infected by pathogens, physiological and photosynthetic properties and growth of plants were negatively influenced. Pathogen infection led to a decrease in photosynthesis and modification or damage of the photosynthetic apparatus, which might be the result of down-regulation of photosynthesis or damage of the photosynthetic apparatus. Both maximum/potential quantum efficiency (Fv/Fm) and the maximum primary 
yield (Fv/F0) of photochemistry of PS II are related to photosynthetic efficiency of plant leaves. Chlorophyll fluorescence analyses showed that PSII photochemical efficiency is decreased by viral infection (Gao et al., 2011).

Numerous studies have shown enhanced resistance of plants to insect herbivores. Si may act directly on insect herbivores, leading to a reduction in insect performance and plant damage. A further indirect effect of Si may be to increase tolerance of plants to abiotic stresses, notably water stress, which can lead to a reduction in insect numbers and plant damage. Increased physical resistance based on solid amorphous silica has long been considered the major mechanism of Si-mediated defences of plants. Physical resistance involves reduced digestibility and/or increased hardness and abrasiveness of plant tissues because of silica deposition, mainly as opaline phytoliths, in various tissues, including epidermal silica cells (Reynolds et al., 2009).

Diseases incidence. Scientists have tested the effects of Si on several components of resistance to blast using susceptible, partially resistant, and completely resistant rice cultivars. They found that, regardless of the cultivar resistance, $\mathrm{Si}$ application increased the incubation period and decreased the number of sporulating lesions, lesion size, rate of lesion expansion, and the number of spores per lesion (Ma, 2004).

Foliar application of $\mathrm{Si}$ has been reported to be effective in inhibiting powdery mildew development on cucumber, muskmelon, and grape. Si applied to leaves may deposit on the surface of leaves and play a similar role to that of $\mathrm{Si}$ taken up from the roots (Ma, 2004).

$\mathrm{Si}$ is also effective in increasing resistance to fungal diseases caused by Pythium ultimum and P. aphanidermatum in cucumber roots (Ma, 2004).

Diseases suppressed by Si nutrition (Meena et al., 2014) include:

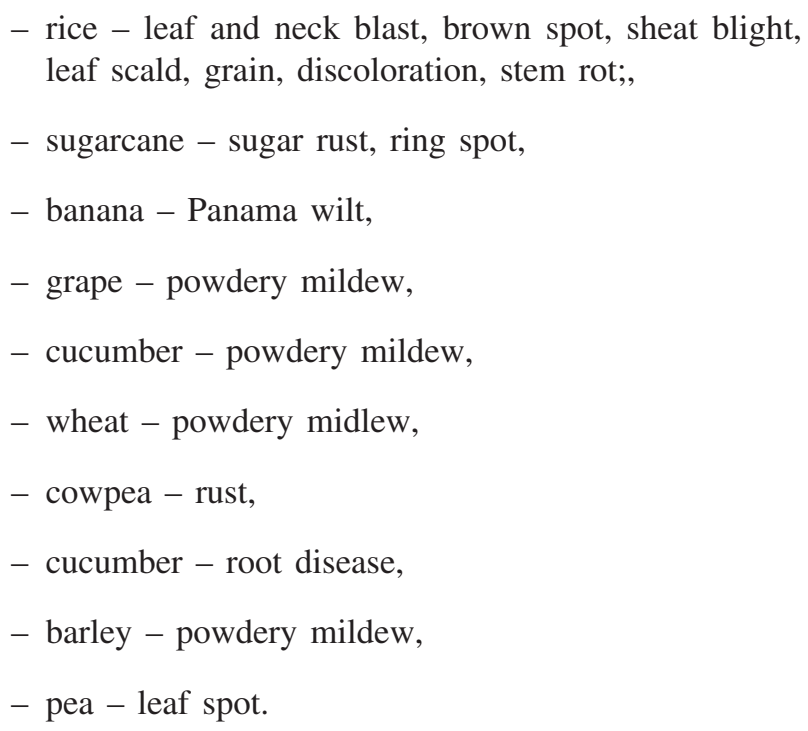

Pests incidence. In a field study, a positive relationship between the $\mathrm{Si}$ content of rice and resistance to the brown planthopper has been observed (Ma, 2004).
Pests suppressed by Si nutrition (Meena et al., 2014) include:

- rice - stem maggot, green leaf hopper, brown plant hopper, leaf spider, stem borer, grey garden slug, mites,

- wheat - green bug, red flour beetle,

- sorghum - green bug,

- corn - leaf aphid, borer,

- sugercane - stalk borer, stem borer,

- grape - fruit cracking.

Abiotic stresses. Si is known to effectively mitigate various abiotic stresses such as manganese, aluminum and heavy metal toxicity, and salinity, drought, chilling and freezing stresses. The key mechanisms of Si-mediated alleviation of abiotic stresses in higher plants include (Liang et al., 2007):

- stimulation of antioxidant systems in plants,

- complexation or co-precipitation of toxic metal ions with $\mathrm{Si}$,

- immobilisation of toxic metal ions in growth media,

- uptake processes, and

- compartmentation of metal ions within plants.

Si can help to mitigate the followed abiotic stress factors in plants (Meena et al., 2014):

- physical stress - lodging, drought, radiation, high temperature, freezing, UV etc.;

- chemical stress - salinity in rice and wheat, Mn toxicity in bean, Al toxicity in rice, Fe toxicity in sugarcane, $\mathrm{Cd}$ toxicity in wheat, rice and maize.

\section{BIOFORTIFICATION}

There is a green line through the mode of action of $\mathrm{Si}$ in response to abiotic and biotic stress, which includes fortification of the structural integrity of cell walls, the stimulation of synthesis of defence components, and contribution to osmotic adjustment together with ion balance (homeostasis) (Haneklaus et al., 2018). Homeostasis is maintained most efficiently by balanced nutrient ratios in plant tissues, which then foster crop productivity, quality, and plant health, while excessive loads of minerals will reduce yield. A unique characteristic of $\mathrm{Si}$ is that it is taken up as a weak acid, $\mathrm{Si}(\mathrm{OH})_{4}$, and by biomineralisation through a successive loss of water; heavy metals are bound in phytoliths, and $\mathrm{SiO}_{2}$ is finally deposited in cell walls (Haneklaus et al., 2018).

The application of 50 or $100 \mathrm{mg} \cdot \mathrm{l}^{-1}$ of $\mathrm{Si}$ to nutrient solution allows to obtain $\mathrm{Si}$ biofortified leafy vegetables for 
fresh-cut (ready to use) products. Bioaccessibility values were found to be higher compared to plants that were not biofortified; this would allow a greater uptake during the digestion process. Si-biofortified foods are a valuable coadjuvant in the prevention of bone health (D'Imperio et al., 2016).

Biofortification can be achieved through two mechanisms (D'Imperio et al., 2016):

- modifying the content of some microelements in the edible parts of the plant,

- increasing bioavailability by reducing anti-nutritional factors and favouring or increasing expression of nutritional factors.

\section{SILICIC ACID AGROTECHNOLOGY (SAAT)}

The application of stabilised silicic acid is called silicic acid agro technology (SAAT). This technology was developed by Dr. Henk-Maarten Laane (Bent, 2014). SAAT has been shown to be very effective on almost every crop, with increased root system size, longer stem/tillers, leaf area and chlorophyll content and nutrient uptake, resulting in 15-50\% more yield and higher quality (Bent, 2014). SAAT also decreases biotic and abiotic stresses. Due to a (much) lower infection rate, pesticide use can be reduced by (at least) $50 \%$. The product is safe (for the plant, the soil, the farmer and the consumer) and ecologically friendly.

Many studies have been conducted to determine if Si has an effect on tomato plants (Bent, 2014). Bent reported that SAAT technology can increase the yield of tomatoes up to $31 \%$ based on research done in Asia and Europe in 2012-2013. For tomato, Bent (2014) recommended to use SAAT technology from transplant age to full production of fruit after every 8-12 days. Si effects on young transplanted tomato plants include increased stem length and diameter at early growing stages (Olle and Schnug, 2016a). Similarly, Olle (2014) observed the same results with cucumber in early growing stages. For later growing stages this was confirmed earlier by Bent (2014). Experiments confirm also earlier findings from Olle and Schnug (2016b), who observed that foliar applied $\mathrm{Si}$ increased plants concentration of $\mathrm{P}$ and $\mathrm{K}$, giving the plant a better supply for the higher demand in early growing stages.

\section{SUMMARY}

$\mathrm{Si}$ is the second most abundant element both on the surface of the earth and in the soil. Si in plants leads to increased yield in horticulture production. This nutrient has multiple direct and indirect beneficial effects on growth and development of many plants. Si has beneficial effects on plants that are exposed to abiotic and biotic stresses. Si enhances tolerance of plants to metals toxicity. Si uptake by plants improves agricultural crop quality and yield. Si application could therefore improve crop production under adverse cli- mate and soil conditions. Si can influence positively plant growth and yield, in particular, under stress conditions. Si may increase uptake and translocation of mineral elements in plants. The application of stabilised silicic acid is called the 'silicic acid agro technology' (SAAT). SAAT has been shown to increase root system size, length of stem/tillers, leaf area and chlorophyll content and nutrient uptake, resulting in higher yield and improved quality. SAAT also decreases biotic and abiotic stresses.

\section{REFERENCES}

Ali, S., Farooq, M. A., Yasmeen, T., Hussain, S., Arif, M. S., Abbas, F., Bharwana, S. A., Zhang, G. (2013). The influence of silicon on barley growth, photosynthesis and ultra-structure under chromium stress. Ecotoxicol. Environ. Safety, 89, 66-72.

Balakhnina, T., Borkowska, A. (2013). Effects of silicon on plant resistance to environmental stresses. Int. Agrophys., 27 (2), 225-232.

Bent, E. (2014). Silicon Solutions. Helping plants to help themselves. Sestante Edizioni, Bergamo. 183 pp.

Chen, W., Yao, X., Cai, K., Chen, J. (2011). Silicon alleviates drought stress of rice plants by improving plant water status, photosynthesis and mineral nutrient absorption. Biol. Trace Elem. Res., 142 (1), 67-76.

Currie, H. A., Perry, C. C. (2007). Silica in plants: Biological, biochemical and chemical studies. Ann. Bot., 100 (7), 1383-1389.

Datnoff, L. E., Snyder, G. H., Korndörfer, G. H. (eds.) (2001). Silicon in Agriculture Vol. 8.. Elsevier. 403 pp.

D'Imperio, M., Renna, M., Cardinali, A., Buttaro, D., Santamaria, P., Serio, F. (2016). Silicon biofortification of leafy vegetables and its bioaccessibility in the edible parts. J. Sci. Food Agricult., 96 (3), 751-756.

Durner, E. F. (2013). Principles of Horticultural Physiology. Gutenberg Press Ltd., Tarxien, Malta. 405 pp.

Epstein, E. (2009). Silicon: Its manifold roles in plants. Ann. Appl. Biol., 155 (2), 155-160.

Farooq, M. A., Dietz, K. J. (2015). Silicon as versatile player in plant and human biology: Overlooked and poorly understood. Frontiers Plant Sci., 6, 994.

Gao, D., Cai, K., Chen, J., Luo, S., Zeng, R., Yang, J., Zhu, X. (2011). Silicon enhances photochemical efficiency and adjusts mineral nutrient absorption in Magnaporthe oryzae infected rice plants. Acta Physiol. Plant., 33 (3), $675-682$.

Gomes, F. B., Moraes, J. C. D., Santos, C. D. D., Goussain, M. M. (2005). Resistance induction in wheat plants by Si and aphids. Scientia Agricola, 62 (6), 547-551.

Greger, M., Landberg, T., Vaculik, M., Lux, A. (2011). Silicon influences nutrient status in plants. In: Proceedings of the 5th International Conference on Silicon in Agriculture. 13-18 September 2011, Beijing, China. Book of Abstracts, pp. 57-58.

Guntzer, F., Keller, C., Meunier, J. D. (2012). Benefits of plant Si for crops: A review. Agron. Sust. Devel., 32 (1), 201-213.

Haneklaus, S. H., Bloem, E., Schnug, E. (2018). Hungry plants: A short treatise on how to feed crops under stress. Agriculture, 8 (3), 1-13.

Hashemi, A., Abdolzadeh, A., Sadeghipour, H. R. (2010). Beneficial effects of silicon nutrition in alleviating salinity stress in hydroponically grown canola, Brassica napus L., plants. Soil Sci. Plant Nutr., 56 (2), 244-253.

Jana, S., Jeong, B. R. (2014). Silicon: The most under-appreciated element in horticultural crops. Trends Horticult. Res., 4 (1), 1-19.

Laing, M. D., Gatarayiha, M. C., Adandonon, A. (2006). Silicon use for pest control in agriculture: A review. Proc. South Afri. Sugar Technol. Assoc., 80, 278-286. 
Liang, Y., Si, J., Römheld, V. (2005). Silicon uptake and transport is an active process in Cucumis sativus. New Phytologist, 167 (3), 797-804.

Liang, Y., Sun, W., Zhu, Y. G., Christie, P. (2007). Mechanisms of silicon-mediated alleviation of abiotic stresses in higher plants: A review. Environ. Poll., 147 (2), 422-428.

Ma, J. F. (2004). Role of silicon in enhancing the resistance of plants to biotic and abiotic stresses. Soil Sci. Plant Nutr., 50 (1), 11-18.

Ma, J. F. Yamaji, N. (2006). Silicon uptake and accumulation in higher plants. Trends Plant Sci., 11 (8), 392-397.

Meena, V. D., Dotaniya, M. L., Coumar, V., Rajendiran, S., Kundu, S., Rao, A. S. (2014). A case for silicon fertilization to improve crop yields in tropical soils. Proc. Nat. Acad. Sci. India, Section B: Biol. Sci., 84 (3), 505-518.

Olle, M. (2013). The effect of effective microorganisms (Em) on the yield, storability and calcium content in swede. XVII. In: International Plant Nutrition Colloquium and Boron Satellite Meeting Proceedings Book. Istanbul/Turkey, pp. 714-715.

Olle, M. (2014). The effect of silicon on the organically grown cucumber transplants growth and quality. In: Proceedings of 16th World Fertilizer Congress of CIEC. CIEC, Rio de Janeiro, pp. 90-92.

Olle, M. (2015). Methods to Avoid Calcium Deficiency on Greenhouse Grown Leafy Crops. LAP LAMBERT Academic Publishing. 118 pp.

Olle, M., Schnug, E. (2016a). The effect of foliar applied silicic acid on growth and chemical composition of tomato transplants. J. Kulturpflanzen, 68 (8), 241-243.

Olle, M., Schnug, E. (2016b). The influence of foliar applied silicic acid on $\mathrm{N}, \mathrm{P}, \mathrm{K}, \mathrm{Ca}$ and $\mathrm{Mg}$ concentrations in field peas. J. Kulturpflanzen, 68 (1), $7-10$.

Olle, M. (2017). The effect of silicon on the organically grown iceberg lettuce growth and quality. Agraarteadus J. Agr. Sci., 28 (2), 82-86.

Raven, J. A. (2003). Cycling silicon - the role of accumulation in plants. New Phytol., 158 (3), 419-421.

Received 7 August 2019

Accepted in the final form 11 May 2020
Reddy, K. S., Menary, R, C. (1990). Nitrate reductase and nitrate accumulation in relation to nitrate toxicity in Boronia megastigma. Physiol. Plant. 78 (3), 430-434.

Reynolds, O. L., Keeping, M. G., Meyer, J. H. (2009). Si-augmented resistance of plants to herbivorous insects: A review. Ann. Appl. Biol., 155 (2), 171-186.

Reynolds, O. L., Padula, M. P., Zeng, R., Gurr, G. M. (2016). Silicon: Potential to promote direct and indirect effects on plant defence against arthropod pests in agriculture. Frontiers in Plant Sci., 7, 744.

Richmond, K. E., Sussman, M. (2003). Got silicon? The non-essential beneficial plant nutrient. Curr. Opin. Plant Biol., 6 (3), 268-272.

Rizwan, M., Ali, S., Ibrahim, M., Farid, M., Adrees, M., Bharwana, S. A., Zia-ur-Rehman, M., Qayyum, M. F., Abbas, F. (2015). Mechanisms of silicon-mediated alleviation of drought and salt stress in plants: A review. Environ. Sci. Poll. Res., 22 (20), 15416-15431.

Rodrigues, F. A., Datnoff, L. E. (2005). Silicon and rice disease management. Fitopatol. Brasil., 30 (5), 457-469.

Romero-Aranda, M. R., Jurado, O., Cuartero, J. (2006). Silicon alleviates the deleterious salt effect on tomato plant growth by improving plant water status. J. Plant Physiol., 163 (8), 847-855.

Smith, A. (2011). Silicon's key role in plant growth. Austral. Grain, March-April, pp. 35.

Snyder, G. H., Matichenkov, V. V., Datnoff, L. E. (2006). Silicon. In Barker, A., Pilbeam, D. (eds.). Handbook of Plant Nutrition. Taylor and Frances, Boca Raton, pp. 551-568.

Tubana, B. S., Babu, T., Datnoff, L. E. (2016). A review of Si in soils and plants and its role in US agriculture: History and future perspectives. Soil Sci., 181 (9/10), 393-411.

Zhu, Y., Gong, H. (2014). Beneficial effects of Si on salt and drought tolerance in plants. Agron. Susta. Devel., 34 (2), 455-472.

Vaculík, M., Landberg, T., Greger, M., Luxová, M., Stoláriková, M., Lu, A. (2012). Si modifies root anatomy, and uptake and subcellular distribution of cadmium in young maize plants. Ann. Bot., 110 (2), 433-443.

Vasanthi, N., Saleena, L. M., Raj, S. A. (2014). Si in crop production and crop protection. A review. Agricult. Rev., 35 (1), 14-23.

\section{SILĪCIJS ILGTSPĒJĪGĀ AUGKOPĪBAS SISTĒMĀ}

Apskatā aplūkota silīcija nozīme augkopībā. Šì elementa klātbūtne paaugstina augu produktivitāti un kvalitāti, īpaši biotiska un abiotiska stresa apstākḷos. Silīcija lietošana stabilās silīcijskābes veidā (silīcijskābes agrotehnika) ir svarīgs elements ilgtspējīgā augkopības stratēgijāa 